INDEPENDENT JOURNAL OF MANAGEMENT \& PRODUCTION (IJM\&P)

http://www.ijmp.jor.br

v. 11, n. 8, Special Edition ISE, S\&P - May 2020

ISSN: 2236-269X

DOI: 10.14807/ijmp.v11i8.1220

\title{
PROSPECTS FOR IMPLEMENTATION OF CORPORATE ENVIRONMENTAL RESPONSIBILITY CONCEPT: THE EU EXPERIENCE FOR UKRAINE
}

Bohdan Andrushkiv

Ternopil Ivan Puluj National Technical University, Ukraine E-mail: andrushkivbohdan@gmail.com

Liliya Melnyk

Ternopil Ivan Puluj National Technical University, Ukraine E-mail: liliana.mel0512@gmail.com

Viktor Palianytsia Ternopil Ivan Puluj National Technical University, Ukraine E-mail:vik03@ukr.net

Olena Sorokivska Ternopil Ivan Puluj National Technical University, Ukraine E-mail: soroka220996@gmail.com

Roman Sherstiuk IJTM\&P

Ternopil Ivan Puluj National Technical University, Ukraine E-mail:romsher85@gmail.com

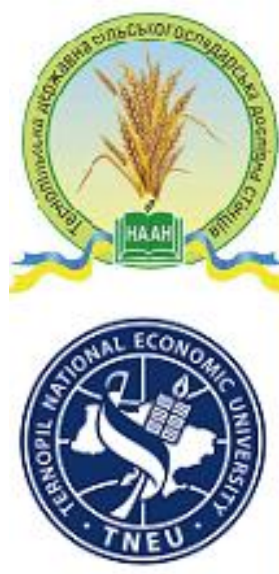

Submission: 12/24/2019 Accept: $1 / 7 / 2020$

\section{ABSTRACT}

A comparative analysis of the main indicators of ecological sustainability in Ukraine and European countries has been done and the economic indicators of nature use in Ukraine have been studied. The purpose of this article is to study the experience and development peculiarities of corporate environmental responsibility, as well as the implementation of better European environmental practice in Ukrainian business. The research methodology concerns to the study of the Environmental Sustainability Index of Ukraine and European countries, as well as the Eco-innovations Index. The key criteria for corporate environmental responsibility has been identified based on the analysis results and a list of factors affecting the environmental responsibility of the enterprise has been formed. The conceptual framework of corporate environmental responsibility in Ukraine with application European principles and approaches for creating a favourable business environment has been developed. 
DOI: 10.14807/ijmp.v11i8.1220

Keywords: environmentally responsible business; European experience; environmental responsibility concept; sustainable development; environmental indicators.

\section{INTRODUCTION}

The concept of corporate environmental responsibility in the European Union has been developed since 1970s in response to large-scale environmental problems caused by activities of powerful corporations. The term "environmental responsibility" derives from the conceptual framework of Corporate Social Responsibility.

Ukraine's course towards the European integration led to reject the state paternalism practise, understand the enterprise role as a public institution, and develop a new approach to the efficiency assessment and enterprise performance. The environmental responsibility functions of the enterprise have been starting to gain a great importance in increasing business competitiveness, achieving higher productivity and profitability.

The environmental measures, environmental infrastructure and environmental programs are used to support pro-environmental enterprise policy. Corporate environmental responsibility (CER) contributes to the effective approaches, methods, technologies of corporate environmental management. The transformation of public values and priorities requires the change introduction into environmental management practice, the integration of principles, methods and tools of environmental responsibility in the enterprise activity.

There is a need for scientific substantiation and further development of CER types and levels caused by the growing relevance of social and corporate environmental responsibility. In general, the environmental responsibility of a business shows its impact on the environmental situation, and the responsibility of those who make business decisions concerning the use of natural resources. It should be noticed that the term "environmental responsibility" is based on a broad interpretation of "ecology" term, its identification with the impact on the environment.

In this aspect, the environmentally friendly behaviour of a person, any social group, or community, has been seen as its multiplier effect on the environment. This methodological approach makes it possible to consider the environmental responsibility as a complex systemic phenomenon, which reveals the interaction of business entities and biological systems.

Widely known is to interpret the term of "environmental responsibility" on the basis of a related term "responsibility". As a philosophical category, responsibility reflects the 
DOI: 10.14807/ijmp.v11i8.1220

objective, historically specific nature of the relationship between personality, community, and social groups from the standpoint of conscious implementation of mutual requirements and duties.

In psychology, "responsibility" is the set of control types that are used to monitor any person in their activity in terms of implementation of the adopted rules and regulations. The several types of responsibility can be classified according to different criteria. Thus, according to content, there is economic, political, legal, moral, social responsibility. By the subject there is personal, group, and collective responsibility.

Having analysed the components of the term "environmental responsibility", it is should be noted that it can't be reduced to the personal consciousness or person's activity. The environmental consciousness refers to specific psychological factors related to individuals' propensity to engage in pro-environmental behaviours. Environmental responsibility is based both on the understanding and adoption of ecological interests, and the ability not to harm the environment by human activity. The environmental responsibility of a business is to some extent equated with a responsible citizen who follows the principle: "If I am not a part of the solution to the problem, then I am part of this problem". At the same time, there is an urgent task to ensure the formation of personal and corporate environmental responsibility aimed at the implementation of environmental initiatives.

Nowadays, the environmental responsibility is widely spreading and integrating into business activity of large world companies, corporations and banks. At the same time, it has a significant impact on small and medium businesses. The most influential management thinker P. Drucker noted that an organization can't exist in a vacuum, and therefore it is considered as an integral part of a society that meets its needs (DRUCKER, 1993).

Therefore, an enterprise should minimize its negative impact on the environment, which will increase its credibility in society and more fully meet public needs.

\section{LITERATURE REVIEW}

There is no single approach how to determine the nature of environmental responsibility. Environmental responsibility is interpreted differently by economic thinkers and scientists. According to classical approach, the environmental responsibility arose under environmental law because many companies had to review their environmental policy and take measures to reduce the negative impact of their operation on the environment in order to avoid sanctions. According to neoclassical approach, the environmental responsibility is not only the 
DOI: 10.14807/ijmp.v11i8.1220

result of regulatory and legal constraints, but also the moral responsibility of producers for harming the nature (DES JARDINS, 1998).

The concept of sustainable development is derived from ideas of classical and neoclassical approaches. It combines the restrictions set by environmental legislation and moral obligations of business. According to this concept, the ecological responsibility ceases to be something forced, it turns on the internal rules of business. However, we should note that the company's compliance with the environmental responsibility principles is conditioned not only by ethical but also economic considerations. The theoretical framework for ecological direction of social responsibility were the concept of "ecological modernization", "reflection risk", "new environmental paradigm", “environmental marketing strategies”, etc. (KOLOT et al., 2012).

Many foreign scientists such as Kotler and Lee (2004) and Sims (2003) focus on the values and principles of corporate social and environmental responsibility. The other authors such as Idowu, Leal Filho (2009), Dashwood (2012) and Tulder (2008) examine the corporate environmental responsibility in different countries of the world. The global aspects of corporate environmental responsibility have been described by M. Hopkins (1999). A few studies analyze the advantages and disadvantages of corporate environmental responsibility (ZADEK, 2001).

The Ukrainian scientists Kyrylyuk and Mamon (2011), Kolot and Grishnova (2012), Aloni (2015), Baiura (2017) and Musina and Kwasha (2018) contribute to the study of environmentally-oriented business in Ukraine.

Both foreign and scientists have contributed to the scientific ideas of social and environmental responsibility. Des Jardins (1998) determines that the environmental responsibility of the corporation, company, enterprise, institution, and organization combining social aspects is able to solve the ecological issues both in the business and beyond, i.e. at the municipal, regional, national, and global levels. In other words, it is fair business practice, environmental protection, resource-saving technologies, health care and safe working conditions, as well as macro-level society, aimed at achieving the highest performance and competitiveness, and ensuring social welfare and environmental development.

With regard to the term "environmental responsibility" Fitch (1976) defined CER as the ability of the enterprise to solve social and environmental problems; in this sense, he emphasized the distinction between environmental problems and economic issues. Aloni's study (2015) considers in detail the principles of corporate social and environmental responsibility, and analyses various forms of socio-economic responsibility of the entrepreneur 
DOI: 10.14807/ijmp.v11i8.1220

through the concept of "serving the society", supporting members of a particular social community, socializing young people and people with limited physical abilities, etc. According to the author, the environmental responsibility should first of all become a qualitative personality trait, and then the way of doing business.

Bayura (2017) explores the corporate environmental responsibility as an instrument for minimizing environmental impacts and improving the interaction among three major parties: business, society and the state. The author focuses on the "responsibility to society" as a main component of the corporate environmental responsibility and emphasizes that it consists of providing goods and services and increasing profits, as well as a rational using of natural resources, thereby increasing the environmentalization of manufacturing processes.

The modern models of environmental responsibility penetration into enterprise management have been summarized and systematized in the studies of the above-mentioned scholars. In the meantime, despite the intensification of scientific research in this field, there are no comprehensive studies to increase the level of environmental responsibility in Ukraine.

Thus, the scientific understanding of corporate environmental responsibility in European countries and Ukraine has conducted primarily within economics that studies the combining of company efforts to increase profitability and efficiency with environmental goals. Until now, even in the presence of a large volume of scientific literature on corporate environmental responsibility and social responsibility business strategies, the way of becoming the environmentally responsible business have not yet defined in Ukraine. In this regard, it is relevant to study the European experience in the implementation of corporate social and environmental responsibility.

The purpose of the article is to study the peculiarities of the EU experience concerning the development of corporate environmental responsibility as well as the implementation of better practices in the corporate activity of Ukrainian enterprises.

\section{RESEARCH METHODOLOGY}

In the classical sense, methodology is regarded as a system of methods and means of cognition. We are convinced that methodology should be considered as a doctrine of activity organization, i.e. purposeful activity. The implementation of corporate environmental responsibility concept into practice is a clear expression of such activity by a whole group of people interested in the process. In order to expand the study of theoretical meaning and the 
DOI: 10.14807/ijmp.v11i8.1220

peculiarities of development of corporate environmental responsibility, the empirical research was performed in the article.

Today, the European and world science has applied many indicators concerning green manufacturing and industry as a whole. These indicators include the indices of environmental sustainability and eco-innovation.

The Environmental Performance Index (EPI), designed by the Environmental Law and Policy at Yale University, ranks countries' performance on high-priority environmental issues in two areas: (1) environmental health, which improves with economic growth and prosperity, and (2) ecosystem vitality, which comes under strain from industrialization and expanded economic activity. Within these two policy objectives the EPI scores national performance in ten issue areas comprised of 24 performance indicators. EPI indicators measure country proximity to meeting internationally established targets or, in the absence of agreed targets, how nations compare to one another.

According to the ranking of environmental sustainability index in 2018, Ukraine took the 109th place among 180 countries. Its ranking is lower than other European countries (figure $1)$.

It's should be noted, that the developed European countries have the higher indexes of environmental sustainability. This indicates the significant level of green manufacturing and growing role of environmental component in the industrial development.

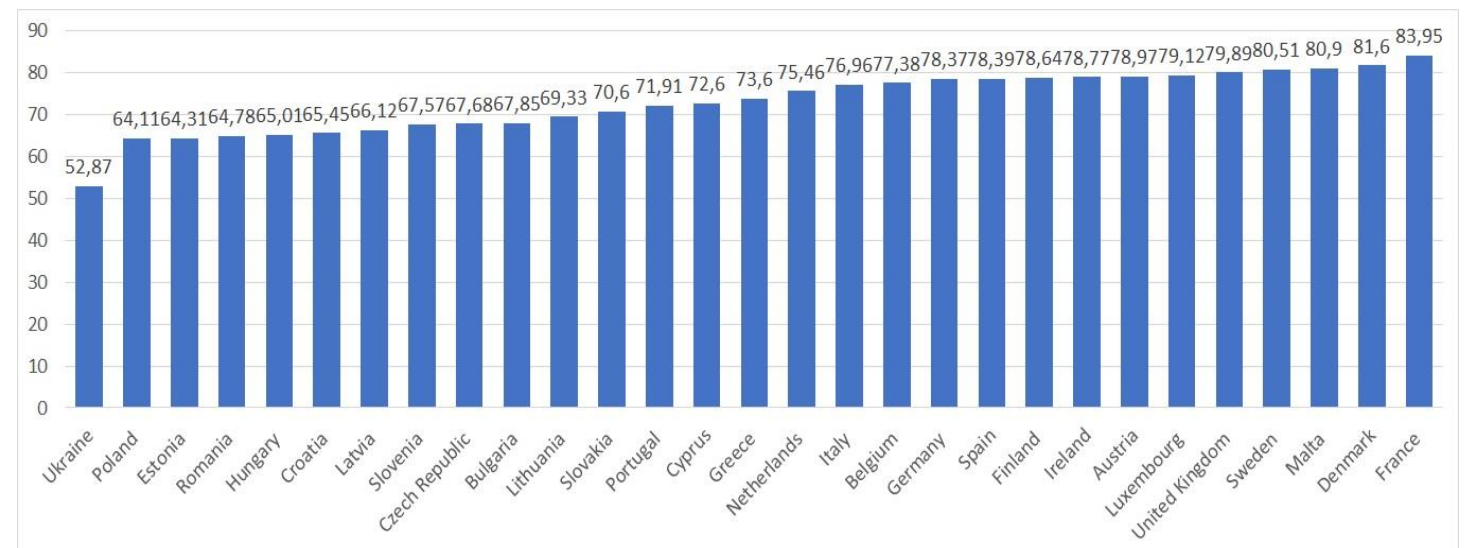

Figure 1: The environmental sustainability index in Ukraine and European countries Source: Wendling et al. (2018)

Environmental innovation is recognized as an indicator of sustainable and balanced development in a competitive environment, and one of the tools that facilitates the introduction of European standards in Ukrainian economic environment. International policy documents and statistical reports, where environmental innovations are considered as the innovations that 
DOI: 10.14807/ijmp.v11i8.1220

increase the efficient use of natural resources from an economic point of view, reduce negative impact of human activity on the environment or improve the ecological stability in ecological system. Implementation of environmental innovation contributes to the development and expansion of market share for environmental goods and services.

Eco-innovation Index illustrates the eco-innovation performance across countries and is based on 16 sub-indicators from eight contributors in five thematic areas: eco-innovation inputs, eco-innovation activities, eco-innovation outputs, resource efficiency outcomes and socio-economic outcomes. Graphical representation of eco-innovation index in European countries for 2018 is shown in Figure 2.

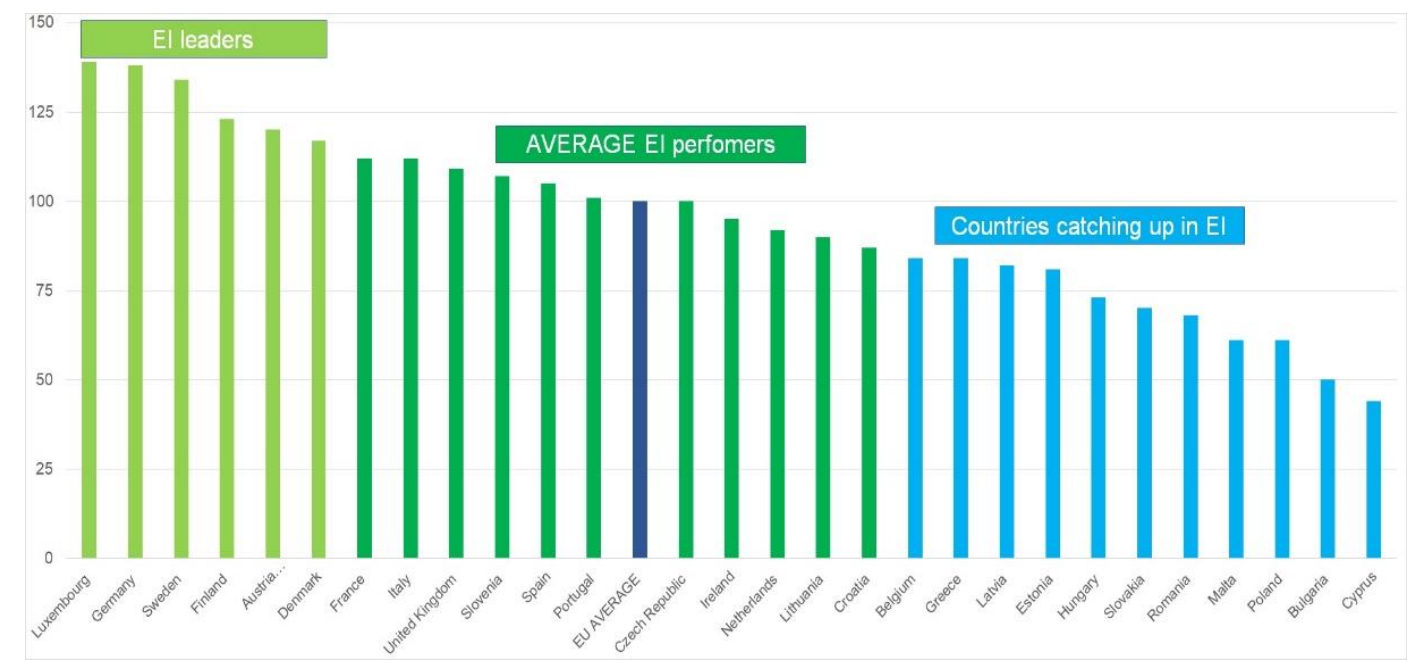

Figure 2: Eco-innovation Index, 2018

Source: Report of European Commission "Eco-innovation Index 2018"

There is currently no official practice of calculating the eco-innovation index in Ukraine. However, according by Musina and Kwasha (2018), the calculated eco-innovation index in Ukraine indicates a decline in eco-innovation activity since 2016. This makes it necessary to study the peculiarities of corporate environmental responsibility concept of EU countries which are leaders in sustainability for meeting established environmental policy goals.

Thus, we can note that under current conditions the environmental responsibility concept contributes to the implementation of certain aspects of greening in the Ukrainian companies' activities through local, regional and global environmental projects and expands their presence on the European market.

\section{RESULTS AND DISCUSSION}


DOI: 10.14807/ijmp.v11i8.1220

Environmental responsibility in Ukraine is a new type of legal responsibility; its occurrence is prescribed by the environmental legislation for committing environmental offenses. Responsibility in environmental law is an important component of legal support of environmental management, environmental restoration and environmental protection facilities.

Environmental responsibility involves not only compliance with environmental legislation, but also the responsibility of the company before present and future generations for the environmental preservation, which manifests in environmental management, saving production and consumption and other activities aimed at improving the environmental situation.

In our opinion the essence of environmental responsibility deals with three main functions: stimulative, preventive and compensatory aimed at maintaining the stable balance of economic and environmental interests in economic activities through the prevention or reduction of environmental losses. This approach requires a comprehensive implementation of the environmental values in the management practice and organizational culture.

According to a survey of business executives were found that most Ukrainian enterprises recognize only legal environmental responsibility, and many organizations follow it for the sake of economic benefits. At the same time, every year a growing number of companies is aware of severity of the global environmental crisis and they contribute to the environmental preservation.

Ecological situation in Ukraine has still a negative impact both on the public health and livelihoods of ecosystem. Bad environmental situation (increase in emissions and discharges of pollutants into the atmosphere and water, penalties for violations in the field of environmental protection) is also evidenced by the annual increase in the amount of environmental tax.

The increase in the environmental tax is higher than the increase in capital and current expenditure on environmental protection by 2.5 times (table 1). According to data presented in the "National Environmental Policy of Ukraine until 2020", the environment in Ukraine is polluted mainly by mining and metallurgy, chemical industry and energy sector.

Very complicated ecological situation in Ukraine requires a comprehensive implementation of European environmental values at all levels i.e. from personal to public. We have estimated the implementation level of environmental responsibility into management 
DOI: 10.14807/ijmp.v11i8.1220

practices of European enterprises in order to determine the areas of environmental responsibility for domestic companies.

In the European Union, the corporate environmental responsibility is seen as a key factor in increasing the company competitiveness and adhering to environmental standards of citizens and society as a whole. There is a clear understanding that the adherence to the principles of corporate environmental responsibility is the strategic priority of every company and the basis of its sustainable development.

Table 1: Economic indicators of Natural Resource use in Ukraine for 2014-2018, million $\mathrm{UAH}$

\begin{tabular}{|l|c|c|c|c|c|c|c|}
\hline \multirow{2}{*}{ Characteristic } & \multicolumn{5}{c|}{ Years } & \multicolumn{3}{c|}{ Deviation (2018/2014) } \\
\cline { 2 - 9 } & 2014 & 2015 & 2016 & 2017 & 2018 & $+/-$ & $\%$ \\
\hline Environmental tax & 2987.6 & 3123.9 & 3876.5 & 4528.9 & 5124.3 & +2136.7 & 71.5 \\
\hline $\begin{array}{l}\text { Capital expenditures on } \\
\text { environmental protection }\end{array}$ & 7959.9 & 7675.6 & 13390.5 & 11025.5 & 10074.3 & +2114.4 & 26.6 \\
\hline $\begin{array}{l}\text { Current expenditures on } \\
\text { environmental protection }\end{array}$ & 13965.7 & 16915.5 & 19098.2 & 20466.4 & 24317.9 & +10352.2 & 74.1 \\
\hline
\end{tabular}

Source: Report of the State Statistics Service of Ukraine

Based on an in-depth analysis of such sources as: Nigri and Baldo (2018), Cheema and Javed (2017), Handayani, Wahyudi and Suharnomo (2017), Nlandu Mamingi (2011) and Grabara, Bajdor and Mihaescu (2015), we found that the European model of corporate environmental responsibility is characterized by significant state interference, in particular in the economy, employment and the environment. Its main purpose is not profit, but responsible attitude towards workers and society, minimization of negative impact on the environment.

Accordingly, government influences the occupational health and safety, wage level, production volume and services, ecology, employment, and social guarantees. Another important feature of the European model is the significant redistribution of gross domestic product through the state budget (over 45\%), which provides a powerful system of social and environmental protection by attracting funds from public and private sources.

The leadership of the European Union countries shows an example of an environmentally responsible approach, thereby encouraging private organizations. For example, in the Netherlands, it is determined that two percent of all goods purchased by government agencies and enterprises should be environmentally friendly, which encourages private enterprises to invest in this area. It should be noted that in each country of the European Union there are features of corporate environmental responsible, therefore we can distinguish three types of the European model. 
The first type (traditional) includes Austria, Germany, and France. The main feature of this European model of corporate environmental responsibility is the significant state regulation of environmental relations for certain autonomy of entrepreneurs and trade unions. The second type includes Belgium, Norway, and Sweden. These countries are characterized by the active state participation in regulating environmental relations. The third type of the model is typical of the UK (it combines some parts of American and continental models).

According by Kolot and Grishnova (2012) one of the most common approaches defining the corporate environmental responsibility in Europe is an approach based on three criteria, namely: compliance with environmental commitments, efficient energy and raw material management, and stakeholder involvement (table 2).

Thus, the environmentally friendly company operates in such a way, that it does not directly or indirectly aggravate the environment, does not cause direct or indirect damage to the country economy, consumers, population and personnel. The corporate environmental responsibility should ensure the high rates of expanded reproduction and production, economic growth and welfare, as well as the environmental improvement and protection. Based on a survey of top-managers of industrial enterprises in different regions of Ukraine, it was found that the environmental responsibility of the enterprise is influenced by numerous external and internal factors (figure 3).

Table 2: Criteria for corporate environmental responsibility

\begin{tabular}{|c|c|}
\hline Criteria & Features of corporate environmental responsibility \\
\hline $\begin{array}{l}\text { Compliance with } \\
\text { environmental } \\
\text { commitments }\end{array}$ & $\begin{array}{l}\text { - The company vision is fully consistent with the concept of sustainable } \\
\text { development and the concept of social responsibility; } \\
\text { - the company's strategic priorities are to protect and restore the natural } \\
\text { environment; } \\
\text { - awareness of the fact that the economic system operates within an ecosystem that } \\
\text { is limited; } \\
\text { - the company adheres to and acts in accordance with the requirements of } \\
\text { environmental legislation; } \\
\text { - the company is fully responsible for the damage that has been caused to the } \\
\text { environment; } \\
\text { - a corporate culture based on environmental values is encouraged. }\end{array}$ \\
\hline $\begin{array}{c}\text { Resource } \\
\text { management }\end{array}$ & $\begin{array}{l}\text { - The effective use of natural resources; } \\
\text { - creation and use of renewable energy; } \\
\text { - the company is guided by a system approach to management; } \\
\text { - the company tries to minimize carbon dioxide emissions (if it is related to its } \\
\text { activities); } \\
\text { - there is a constant analysis of environmental achievements and the search for new } \\
\text { environmental solutions; } \\
\text { - the company continuously analyzes environmental costs and benefits. }\end{array}$ \\
\hline
\end{tabular}


ISSN: 2236-269X

DOI: 10.14807/ijmp.v11i8.1220

\begin{tabular}{|c|c|}
\hline $\begin{array}{l}\text { Stakeholder } \\
\text { involvement }\end{array}$ & $\begin{array}{l}\text { - The company informs local communities and authorities about the environmental } \\
\text { consequences of its activities; } \\
\text { - the company is responsible to the community and other stakeholders for its current } \\
\text { and future activities, as well as for actions committed in the past; } \\
\text { - the company takes into consideration the stakeholder's thoughts and wishes } \\
\text { concerning development and projects implementation; } \\
\text { - the company's activity is transparent, including information on its impact on the } \\
\text { environment; } \\
\text { - the company constantly analyzes and regularly reports on its environmental } \\
\text { impact. }\end{array}$ \\
\hline
\end{tabular}

External (exogenous) factors are those factors influencing the enterprise activity in the field of ecology, and determined by the state and characteristics of the environment in which the enterprise operates. This factors act beyond the company, but direct or indirect contribute to making managerial decisions and change inside the organization.

Internal (endogenous) factors are factors influencing the enterprise activity in the field of ecology that are occurred inside the business and these generally under control of the enterprise.

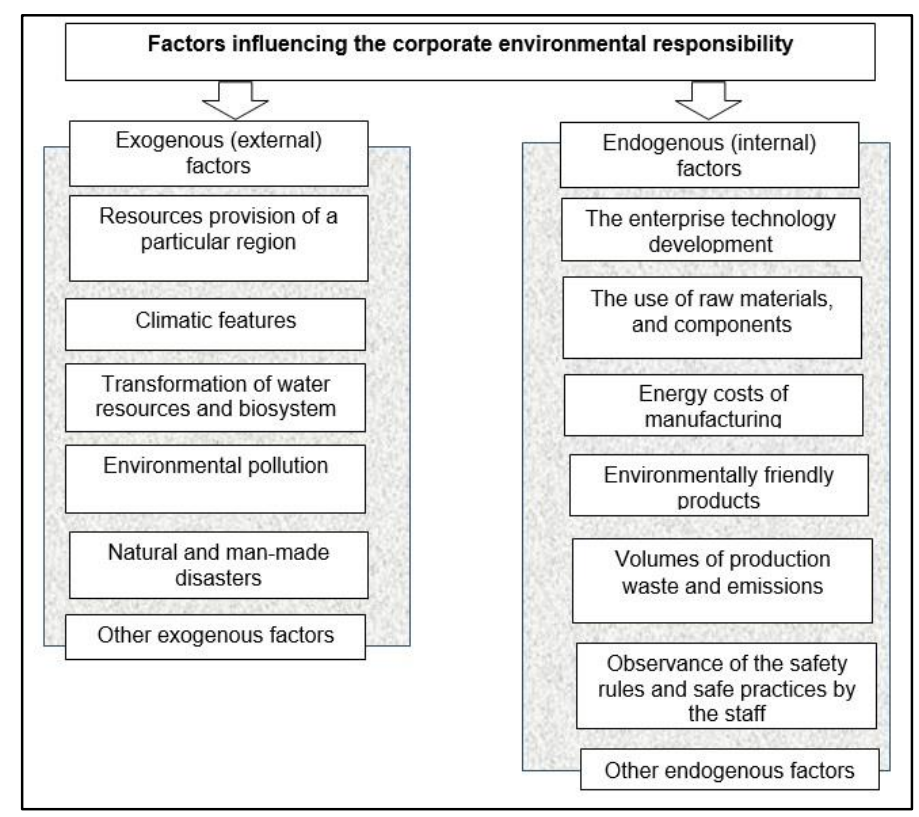

Figure 3: Factors influencing the corporate environmental responsibility

Thus, a comprehensive assessment of environmental factors and its impact on the enterprise activity is a basis for the formation of its environmental responsibility. Being an environmentally-friendly enterprise is possible if there is a constant counteraction to internal and external threats affecting its activities in the field of ecology.

Each enterprise must have an individual mechanism of nature conservation that takes into account the company size, the sphere of its activity, and the corporate culture. However, the most measures (in the field of corporate environmental responsibility) to minimize the 
ISSN: $2236-269 X$

DOI: 10.14807/ijmp.v11i8.1220

negative impact of company's activity on the environment are unified.

Consequently, the research results show that nowadays there is a need to introduce a better European practice of corporate environmental responsibility in Ukraine. The schematic representation of CER model is shown in figure 4.

\begin{tabular}{|c|c|}
\hline \multicolumn{2}{|c|}{$\begin{array}{l}\text { Advisory bodies and environmental initiatives of the European Union: } \\
\text { - The European Council } \\
\text { - European Investment Bank provides credit and investments for the environmental } \\
\text { projects } \\
\text { - The European Commission published a Green Paper "Promoting a European framework } \\
\text { for corporate social responsibility" } \\
\text { - EU Multi-Stakeholder Forum on ERB is founded in order to promote the environmental } \\
\text { initiatives of business } \\
\text { - Environmental Management and Audit (EMAS) is developed by the European } \\
\text { Commission for companies and other organizations to evaluate, report, and improve their } \\
\text { environmental performance }\end{array}$} \\
\hline Consultations & tional $\square$ Trainings \\
\hline \multicolumn{2}{|c|}{ Introduction of European environmental responsibility principles in Ukrainian business } \\
\hline 5 & 5 \\
\hline $\begin{array}{l}\text { Internal environmental responsibility: } \\
\text { - Compliance with environmental } \\
\text { legislation } \\
\text { - Implementation of environmental } \\
\text { innovations } \\
\text { - Modernization and upgrading of } \\
\text { equipment } \\
\text { - Introduction of European environmental } \\
\text { regulations } \\
\text { - Production of environmentally friendly } \\
\text { goods } \\
\text { - Increasing the manufacturing greening } \\
\text { - Automation of manufacturing processes } \\
\text { - Transparency of environmental activities } \\
\text { and availability of reporting information } \\
\text { - Formation of "environmental awareness" } \\
\text { of entrepreneurs and employees }\end{array}$ & $\begin{array}{l}\text { External environmental responsibility } \\
\text { - Building relationships with business } \\
\text { partners, suppliers and customers based } \\
\text { on compliance with European } \\
\text { environmental standards } \\
\text { - Promoting environmental protection at } \\
\text { local level } \\
\text { - Interaction with local communities and } \\
\text { local authorities in order to implement } \\
\text { the environmental projects } \\
\text { - Reducing environmental risks of the } \\
\text { company's activity } \\
\text { - Conducting enlightenment aimed at } \\
\text { developing the environmentally } \\
\text { conscious society } \\
\text { - Environmentally responsible } \\
\text { investment }\end{array}$ \\
\hline \multicolumn{2}{|l|}{5} \\
\hline \multicolumn{2}{|c|}{$\begin{array}{l}\text { Key results: } \\
\text { - Development of environmentally responsible business in Ukraine according to } \\
\text { European standards } \\
\text { - Change in business approaches: from "consumer society" to "environmentally } \\
\text { conscious society" } \\
\text { - Formation of new entrepreneurs generation who will understand the importance of } \\
\text { environmental component in the manufacturing processes } \\
\text { - Introduction of the best European environmental practice in the Ukrainian business } \\
\text { - The efficient environmental development of Ukrainian businesses, building the } \\
\text { partnership relations with European companies }\end{array}$} \\
\hline
\end{tabular}

Figure 4: A model for implementing European experience in the development of environmentally responsible business in Ukraine

An effective strategy for supporting corporate environmental responsibility is designed to advise, inform and create a favorable institutional environment for the development, implementation of management experience and cooperation with European countries in the application of environmentally friendly technologies and efficient use of resources. 
DOI: 10.14807/ijmp.v11i8.1220

The lack of appropriate legal framework and standards today, the opaque energy pricing and tariff policy, inefficient governmental interference in the business environment, and the lack of information on environmental business opportunities based on experience of European countries can hamper the implementation of corporate social and environmental responsibility in the Ukrainian enterprise activity.

\section{CONCLUSIONS AND RECOMMENDATIONS}

Thus, the main priority measures aimed at implementation of the European experience and development of Ukrainian environmentally friendly business model should include:

- the information support of European countries in implementing measures of greening business;

- the introduction of European scale of ecological indicators for environmental development of enterprises and regions;

- the trainings for managers and Ukrainian business owners in order to create the environmental awareness and implement the European experience;

- the dissemination of information on corporate environmental responsibility, its benefits and the need for society;

- the formation of investment funds and attraction of local budget funds for co-financing of environmental projects, implemented by private companies with the financial and informational support of the European Union;

- the governmental support by providing tax privileges and creating incentives for entrepreneurs who have invested in the environmental projects;

- the introduction of mandatory environmental reporting at national level necessary for companies to quote stocks on the stock exchanges, participate in public tenders, and obtain licenses and others.

The implementation of European corporate environmental responsibility experience should be seen as a key factor in increasing the competitiveness of Ukrainian enterprises and rising living standards of citizens and society as a whole. A key result of this implementation should be a clear understanding that the use of the environmental responsibility principles is a strategic priority for each company and the foundation for sustainable development.

\section{REFERENCES}


ALONI, G. (2015) Problems of corporate social responsibility in corporate strategies big business in Ukraine. Philosophical Sciences. First Independent Scientific Bulletin, n. 4, p. 89-93.

ARIAS, J. C.; PATTERSON, K. (2009) Relationships between corporate social responsibilities' promotion and corporate performance in the multinational corporations. Business Intelligence Journal. vol. 2 n. 1, p. 873-893.

BAIURA, D. (2017) Development of Socially Responsible Corporate Governance in the Context of Harmonization of Interests of Stakeholders. Economic journal of Lesia Ukrainka Eastern European University. Economics and enterprises management, v. 4, n. 12 , p. 39-44.

CHEEMA, S.; JAVED, F. (2017) The effects of corporate social responsibility toward green human resource management: The mediating role of sustainable environment. Cogent

Business and Management, v. 4, n. 1.

DOI: https://doi.org/10.1080/23311975.2017.1310012.

DES JARDINS J. (1998) Corporate Environmental Responsibility. Journal of Business Ethics, v. 17, n. 8, p. 825-838.

DASHWOOD H. S. (2012) The rise of corporate social responsibility. Cambridge: Cambridge University Press.

DRUCKER, P. F. (1993) Managing in Turbulent Times Business \& Economics. Routledge.

\section{EUROPEAN COMMISSION (2019) Eco-innovation Index 2018.}

Available: https://ec.europa.eu/environment/ecoap/indicators/index_en. Access: 7 October 2019.

FITCH, H. G. (1976) Achieving Corporate Social Responsibility. The Academy of Management Review, v. 1, n.1, p. 38-46.

GRABARA, J.; BAJDOR, P.; MIHAESCU, L. (2015) Steps of Sustainable Development Implementation into Enterprise Activities. Management of Sustainable Development, v. 7, n.1, p. 45-49.

HAAN, M.; KONIJN, E. A.; BURGERS, C.; EDEN, A.; BRUGMAN, B. C.; VERHEGGEN, P. P. (2018) Identifying Sustainable Population Segments Using a Multi-Domain Questionnaire: A Five Factor Sustainability Scale. Social Marketing Quarterly, v. 24, n. 4, p. 264-280. DOI: https://doi.org/10.1177/1524500418794019.

HANDAYANI, R.; WAHYUDI, S.; SUHARNOMO, S. (2017) The effects of corporate social responsibility on manufacturing industry performance: The mediating role of social collaboration and green innovation. Business: Theory and Practice, v. 18, p. 152-159.

DOI: https://doi.org/10.3846/btp.2017.016.

HOPKINS, M. (1999) The Planetary Bargain Corporate Social Responsibility Comes of Age. Palgrave Macmillan UK. DOI: 10.1007/978-1-349-27066-8

IDOWU, S. O.; LEAL FILHO, W. (2009) Global practices of corporate social responsibility. Springer-Verlag Berlin Heidelberg, 508 p.

KOLOT, A. M.; GRISHNOVA, O. A. (2012) Social responsibility: the theory and practice of development. Kyiv: KNEU.

KOTLER, P.; LEE, N. (2004) Corporate social responsibility. Wiley; 1st edition. 
KYRYLYUK, V. C.; MAMON E. M. (2011) Principles of formation of an ecologically oriented strategy of an industrial enterprise. Metallurgical heat engineering, v. 3, n. 18, p. 113-118.

LEPIKHIN, V. V.; LEPIKHINA, T. L.; LITVINOVA, S. V. (2015) Sustainable Development of Industrial Enterprises Based on Ecologization. Mediterranean Journal of Social Sciences, v. 6, n. 3, p. 5.

LU, X.; XU, F. (2018) Empirical research on EPR practices performance and governance mechanism from the perspective of green supply chain. Sustainability, v. 10, n. 12. DOI: https://doi.org/10.3390/su10124374.

MAMINGI, N. (2011) Enterprise and Sustainable Development: Role, Challenges and Opportunities. Journal of Economics and Sustainable Development, v. 2, n. 11-12, p. 1626.

MIRIAM, J.; RADOSLAV, J. (2017). The assessment of corporate social responsibility: Approaches analysis. Entrepreneurship and Sustainability Issues, v. 4, n. 4, p. 441-459. DOI: https://doi.org/10.9770/jesi.2017.4.4(4).

MUSINA, L.; KVASHA, T.; KHLOBYSTOV, E. V. (2018) Eco-innovation index as a tool for evaluating innovation performance in the context of sustainable development. Sustainable development - 21st century: management, technologies, models. Discussions 2018: a collective monograph. Kyiv, 2018.

NIGRI, G.; BALDO, M. D. (2018) Sustainability reporting and performance measurement systems: How do small- and medium-sized benefit corporations manage integration? Sustainability, v. 10, n. 12, 4499. DOI: https://doi.org/10.3390/su10124499.

SIMS, R. R. (2003) Ethics and Corporate Social Responsibility: Why Giants Fall. Greenwood Publishing Group.

STATE STATISTICS SERVICE OF UKRAINE (2019) Economic Indicators of Natural Resources in Ukraine in 2014-2018. Available: http://ukrstat.gov.ua. Access: 27 October 2019.

TULDER, R. V. (2008) The international business-society management. Business Ethics Quarterly, v. 18, n. 1, p. 126-135.

VERKHOVNA RADA OF UKRAINE (2007) Concept of the national environmental policy of Ukraine for the period up to 2020.

Available: https://zakon.rada.gov.ua/laws/show/880-2007-\%D1\%80. Access: 10 October 2019.

WENDLING, Z. A.; EMERSON, J. W.; ESTY, D. C.; LEVY, M. A.; DE SHERBININ, A.; (2018) Environmental Performance Index. New Haven, CT: Yale Center for Environmental Law \& Policy. Available: https://epi.yale.edu/.

ZADEK, S. (2001) The civil corporation: the new economy of corporate citizenship. Routledge. 